\title{
Qualitative monitoring of corn silage stored in commercial bunker silos and used as feed for dairy cattle in the western region of Santa Catarina State, Brazil
}

\section{Monitoramento da composição bromatológica de silagens de milho ensiladas em silos do tipo trincheira e utilizadas na alimentação de rebanhos leiteiros no Oeste Catarinense}

\author{
Laura Caroline Di Domenico Giombelli ${ }^{1}$; Eduardo Roscamp²; Fabio José Gomes ${ }^{3}$; \\ Claiton André Zotti ${ }^{4}$; Ana Luiza Bachmann Schogor ${ }^{5 *}$
}

\begin{abstract}
Corn ensiling is a feed preservation practice used for ruminant production. During the process of making and opening the silos, the quality of the silage may change due to the entrance of air, which can cause damage and decrease the voluntary intake of the animals. The objective of this work was to evaluate the chemical composition of corn silages during their use in commercial bunker silos, as well as to correlate this with qualitative and quantitative characteristics related to the silage making process. Technical data on silage making and samples were collected from 14 bunker silos, with five samples collected along each silo (at 10, 30, 50, 70 and 90\% of their lengths); additionally, two sampling methodologies were compared ("W" vs. layer collections in silo panels: top, middle and bottom). The values for the $\mathrm{pH}$ and titratable acidity (TA) were significant $(\mathrm{p}<0.05)$ in relation to the sampling method, where the $\mathrm{pH}$ of the top was higher ( $3.8 \pm 0.5)$ than that of the middle and the bottom layers ( $3.6 \pm 0.3$ and $3.5 \pm 0.3$ ); therefore, the TA was lower in the top of the silos. The dry matter, ashes, crude protein, neutral detergent fiber, acid detergent fiber, $\mathrm{pH}, \mathrm{TA}$, as well as the silo sampling method during the unloading of commercial bunker silos did not differ for any of the variables $(\mathrm{p}<0.05)$. Also, the particle size did not differ during the unloading of the commercial bunker silos ( $p>0.05)$. According to the collected technical data, $78.57 \%$ of the bunker silos were built directly on the ground, the harvesting equipment was mostly borrowed from municipalities or farmers' associations (for 35.7 and $28.5 \%$ of the farms, respectively), and in only $64.2 \%$ of the farms, the harvester was sharpened before silage cutting. Good practices were applied during the corn silage process and throughout the use of the silos, homogeneous quality was detected in the western region of Santa Catarina. Either "W" or layer collections can be used to sample corn silage. Key words: Ensiling. Management practices. Penn state particle size separator. Principal component analysis.
\end{abstract}

1 Discente, Curso de Mestrado, Pós-Graduação em Zootecnia, Universidade do Estado de Santa Catarina, UDESC, Campus UDESC Oeste, Chapecó, SC, Brasil. E-mail: lauracdgiombelli@gmail.com

2 Discente, Curso de Graduação em Zootecnia, UDESC, Campus UDESC Oeste, Chapecó, SC, Brasil. E-mail: eduardoroscamp01@ gmail.com

3 Prof., Departamento de Zootecnia, UDESC, Campus UDESC Oeste, Chapecó, SC, Brasil. E-mail: gomes.fj@outlook.com

4 Prof., Departamento de Zootecnia e Programa de Pós-Graduação em Sanidade e Produção Animal, UNOESC, Xanxerê, SC, Brasil. E-mail: claiton.zotti@unoesc.edu.br

5 Prof ${ }^{a}$, Departamento de Zootecnia e Programa de Pós-Graduação em Zootecnia e Programa de Pós-Graduação em Ciência e Tecnologia de Alimentos, UDESC, Campus UDESC Oeste, Chapecó, SC, Brasil. E-mail: ana.schogor@udesc.br

Author for correspondence 


\section{Resumo}

A ensilagem de milho é uma prática de conservação de alimento utilizada na produção de ruminantes. Durante o processo de confecção e abertura do silo, a silagem pode ter alterações em sua qualidade em função da entrada de ar, que pode causar prejuízos e diminuir o consumo dos animais. Objetivou-se avaliar a composição bromatológica das silagens de milho ao longo da utilização, de silos comerciais do tipo trincheira, bem como correlaciona-las com as características qualitativas e quantitativas, relacionadas ao processo de confecção das silagens. Os dados técnicos sobre a confecção da silagem, bem como amostras foram coletas à campo em 14 propriedades, em que foram coletadas cinco amostras ao longo de cada silo (relativos à 10,30,50, 70 e 90\% do seu comprimento), e adicionalmente duas metodologias de amostragem foram comparadas (coletas em "W" $v s$. coletas em estratos do painel do silo: topo, meio e base). Os valores de $\mathrm{pH}$ e AT $(\mathrm{p}<0,05)$, foram significativos em relação ao método de amostragem, em que o $\mathrm{pH}$ do topo foi maior $(3,8 \pm 0,5)$ que o do meio e o da base $(3,6 \pm 0,3$ e $3,5 \pm 0,3)$; portanto, a AT foi menor no topo dos silos. Os resultados encontrados para MS, MM, PB, FDN e FDA, pH e AT, assim como comparado ao método de amostragem do silo não diferiram entre si para nenhuma das variáveis $(\mathrm{p}<0,05)$. Além disso, o tamanho das partículas não diferiu ao longo da utilização dos silos comerciais tipo trincheira $(\mathrm{p}>0.05)$. O levantamento técnico mostrou que $78,57 \%$ dos silos trincheira avaliados foram construídos diretamente no solo, que os equipamentos de colheita utilizados foram emprestados de prefeituras ou associações de agricultores (para 35,7\% e $28,5 \%$ das fazendas), ou que em somente $64,2 \%$ das fazendas o equipamento de colheita foi afiado antes da colheita. Foram observadas boas práticas de ensilagem de milho e homogênea qualidade ao longo do silo. Ambos métodos de coleta, em "W" como em estratos do painel podem ser usados durante amostragem de silagem de milho.

Palavras-chave: Análise de componentes principais. Ensilagem. Penn state particle size separator. Práticas de manejo.

\section{Introduction}

In Brazil, corn silage is the main roughage source used to feed high milk-producing cows (BERNARDES; REGG, 2014). Corn is frequently used due to the ease of the crop preparation and the silage-making process (NUSSIO et al., 2001). In addition, corn has the flexibility to be used to make silages of grains and whole plants (BERNARDES; CHIZZOTTI, 2012). The whole corn plant, with a dry matter (DM) content between 30 and $35 \%$, has a large amount of soluble sugars and, thus, it can provide good microbial fermentation (DEMINICIS et al., 2009). Additionally, the nutritive value of corn silage depends on a set of factors: the choice of the hybrid for planting, the crop density, growth conditions, the degree of maturity, the moisture of the crop when harvested, and the silage conditions themselves (SATTER; REIS, 2012). However, among the factors that can decrease the quality of corn silage, is the aerobic deterioration, which occurs when the silage is exposed to the environment, which has the largest effect; at this time, the process of degradation begins, especially in hot climates (BERNARDES; ADESOGAN, 2012), as can occur in the western region of Santa Catarina state.

Because the silage process has several crucial steps, process failures are not rare, both in the production and in the fermentation of the material. This can impair the quality of the silage and increase the amount of fermentation losses, due to the fact that good fermentation is the result of the conversion of soluble carbohydrates to organic acids, through the action of anaerobic microorganisms (BERNARDES; WEINBERG, 2013). As in the process of opening the silo, losses can be high due to the entrance of air, which leads to degradation by aerobic microorganisms (JUNGES, 2010). These failures are linked to factors ranging from the characteristics of the plant, the operational management of the harvesting and the compaction of the silage material, to the silo shortage, which influences the silage fermentation process, and can alter its chemicalphysical composition (NEUMANN et al., 2007). This deterioration during the unloading of the silo 
can alter the chemical composition of the silage. Therefore, research that seeks to evaluate the effect of the changes throughout the use of silos should be conducted, such that control tools can be improved and better guidance can be offered to producers and technicians. The objectives of this work were to analyze the physicochemical quality of corn silages in western Santa Catarina during the unloading of commercial bunker silos, as well as their variability, associated with the qualitative and quantitative characteristics of the silage making process. The second objective was to analyze whether sampling methods are representative and equivalent for the evaluation of silage quality.

\section{Material and Methods}

This study was conducted in western Santa Catarina (SC) on 14 dairy farms $(562.8 \pm 102.69$ $\mathrm{m}$ altitude) that produced corn silage in 2016/2017, the first corn harvest period, and stored this corn silage in bunker silos. There was variation in the structure of the silos with respect to their size and the silo coating material (i.e., coated with plastic film, uncoated - directly on the ground, or concrete). Quantitative and qualitative data were collected directly on the farms, ranging from data about corn planting to silo unloading (all collected data are shown in Table 1).

Table 1. Descriptive statistics for qualitative variables of corn silage management practices from 14 commercial bunker silos in the western region of Santa Catarina state, Brazil, during the 2016/2017 crop production season.

\begin{tabular}{|c|c|c|c|c|}
\hline \multirow{2}{*}{ Area of corn crop (\%) } & $<5$ ha & 5-10 ha & $10-15$ ha & $>15$ ha \\
\hline & 64.29 & 7.14 & 21.43 & 7.14 \\
\hline \multirow{2}{*}{$\begin{array}{l}\text { Farmers follow technical assistance for } \\
\text { hybrid planting }(\%)\end{array}$} & Yes & No & & \\
\hline & 85.71 & 14.29 & & \\
\hline \multirow{2}{*}{ Variety of corn for silage $(\%)$} & Dent & Semi dent & Flint & \\
\hline & 14.29 & 64.29 & 21.43 & \\
\hline \multirow{2}{*}{$\begin{array}{l}\text { Method of assessment of the maturity } \\
\text { stage }(\%)\end{array}$} & Milkline & Whole plant & Corn cob & \\
\hline & 50 & 35.71 & 14.29 & \\
\hline \multirow{2}{*}{ Harvest height (\%) } & $20-35 \mathrm{~cm}$ & $35-50 \mathrm{~cm}$ & $>50 \mathrm{~cm}$ & \\
\hline & 71.43 & 21.43 & 7.14 & \\
\hline \multirow{2}{*}{ Silo capacity (\%) } & $>50 \mathrm{t}$ & $50-150 \mathrm{t}$ & $150-250 \mathrm{t}$ & $>250 \mathrm{t}$ \\
\hline & 14.29 & 50 & 21.43 & 14.29 \\
\hline \multirow[t]{2}{*}{ Bunker silo type (\%) } & $\begin{array}{l}\text { Coated with plastic } \\
\text { film }\end{array}$ & $\begin{array}{l}\text { Uncoated (directly } \\
\text { on the ground) }\end{array}$ & \multicolumn{2}{|c|}{ Concrete } \\
\hline & 7.14 & 78.57 & \multicolumn{2}{|c|}{14.29} \\
\hline \multirow{2}{*}{$\begin{array}{l}\text { Owner of the harvesting } \\
\text { equipment }(\%)\end{array}$} & Farmer's association & Municipality & \multicolumn{2}{|c|}{ Particular } \\
\hline & 35.71 & 28.57 & \multicolumn{2}{|c|}{35.71} \\
\hline \multirow{2}{*}{$\begin{array}{l}\text { Frequency of knife sharpening during } \\
\text { the silage making process }(\%)\end{array}$} & Before harvesting & $\begin{array}{c}\text { Before and after the } \\
\text { harvesting }\end{array}$ & \multicolumn{2}{|c|}{$\begin{array}{l}\text { Before and during the } \\
\text { harvesting }\end{array}$} \\
\hline & 64.29 & 7.14 & \multicolumn{2}{|c|}{28.57} \\
\hline \multirow{2}{*}{$\begin{array}{l}\text { Farmer follows some technical } \\
\text { recommendations for silage making (\%) }\end{array}$} & Yes & No & & \\
\hline & 64.29 & 35.71 & & \\
\hline \multirow{2}{*}{$\begin{array}{l}\text { The tractor had wheels with ballasts at } \\
\text { the time of silage compaction }(\%)\end{array}$} & Yes & No & & \\
\hline & 57.14 & 42.86 & & \\
\hline \multirow{2}{*}{$\begin{array}{l}\text { The tractor used extra weight at the time } \\
\text { of silage compaction }(\%)\end{array}$} & Yes & No & & \\
\hline & 64.29 & 35.71 & & \\
\hline
\end{tabular}


continuation

\begin{tabular}{lcccc}
\hline Frequency of plastic & Yes & No & & \\
film covering the silo (\%) & 92.86 & 7.14 & & \\
\hline \multirow{2}{*}{ Delay time to cover silo (\%) } & $<12 \mathrm{~h}$ & $24 \mathrm{~h}$ & $48 \mathrm{~h}$ & $>48 \mathrm{~h}$ \\
& 14.28 & 71.43 & 7.14 & 7.14 \\
\hline Frequency of silage removal per & 1 & 2 & 3 & \\
day (number per day) & 14.28 & 78.57 & 7.14 & \\
\hline Slice size/day from the silo (\%) & $5-10 \mathrm{~cm}$ & $10-15 \mathrm{~cm}$ & $15-20 \mathrm{~cm}$ & $>20 \mathrm{~cm}$ \\
& 7.14 & 21.43 & 57.14 & 14.28 \\
\hline
\end{tabular}

The silage was sampled at five points along each silo, according to the use of silage, per the routine of the dairy farms. Since the length of each silo varied among farms, the collection points were defined as follows: from the total silo size, $10 \%$ of the silo outset and $10 \%$ of the silo end were excluded, totaling $20 \%$ of the silo that was disregarded; the remaining $80 \%$ of each silo was then divided into four portions (corresponding to $20 \%$ each), which resulted in five collection points, and these points were delimited by the use of pegs. In other words, five samples were collected along each silo at 10 , $30,50,70$ and $90 \%$ of its length.

Samples were taken in two sample forms. The "W" type consisted of collecting samples at five points from an imaginary "W" designed on the silo panel, referring to the ends of the $\mathrm{W}$, as described in Figure 1. Secondly, separate "strata" collections were taken, representing the top, middle and bottom of the silo (where the top samples, corresponding to
20-25 cm from the silo surface, were disregarded due to the presence of mold on some farms); the center sample was removed from the geometric center of the silo, and the base sample was taken $20 \mathrm{~cm}$ from the silo base. All samples (approximately 500 g each) were collected in duplicate (for strata, they were collected side by side, with a space of about $20 \mathrm{~cm}$ between samples), and immediately frozen $\left(-4\right.$ to $\left.-10{ }^{\circ} \mathrm{C}\right)$. The project team followed up at least once after the first sample collection, and trained the farmers or managers for subsequent collections. Therefore, the samples were accumulated on each dairy farm, and collected at the end of the collection period. Due to some dairy farmers not annotating the date of collection, it was not possible to calculate the silage use rate (or the withdrawal rate per day of the silo panel). The samples were sent to the Laboratory of Animal Nutrition of Santa Catarina State University (UDESC) for further analysis.

Figure 1. Schematic illustration of the silage sampling strategy using the "W" method.

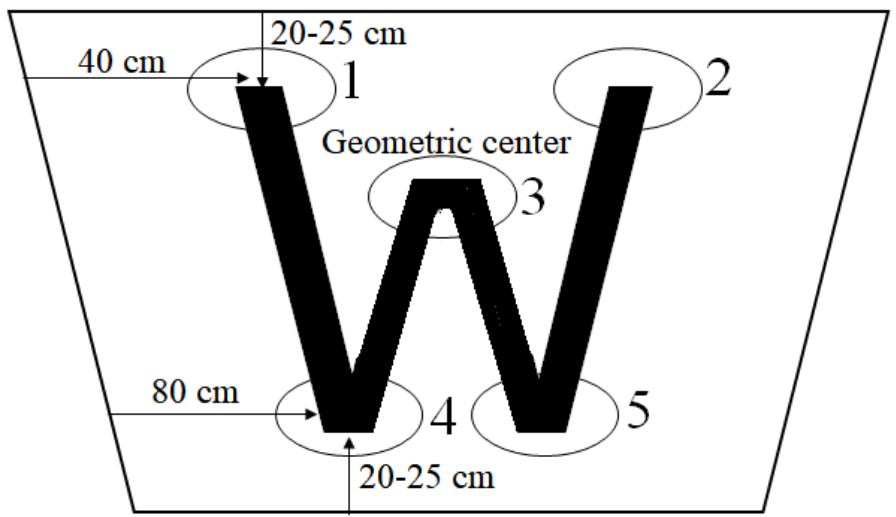

Legend: points 1, 2, 4 and 5 are opposites and symmetric; point 3 is situated in the geometric center of the silo panel. The figure is not drawn to scale. 
The $\mathrm{pH}$ and titratable acidity (TA) analyses were performed according to the methodologies described by Silva and Queiroz (2002). Particle size analysis was performed according to the methodology of the Penn State Particle Size Separator (LAMMERS et al., 1996) adapted by Mari and Nussio (2002). After this analysis, the samples were homogenized according to the type of collection ("W" or "strata") and by collection point ( 1 to 5 ). The chemical analysis of dry matter was determined at $105{ }^{\circ} \mathrm{C}$, and analyses of ash (AOAC, 2000), and crude protein (AOAC, 1990) were performed. Organic matter $(\mathrm{OM})$ was obtained mathematically $(\mathrm{OM}=$ DM - ash). Neutral detergent fiber (NDF) and acid detergent fiber (ADF) analyses were performed as described by AOAC (1997), in polyester bags (KOMAREK, 1993), in which the samples were submitted to an autoclave at $110{ }^{\circ} \mathrm{C}$ for $40 \mathrm{~min}$ (SENGER et al., 2008) in a sequential method. For concentrate samples, $\alpha$-amilase was added (MERTENS, 2002).

Qualitative data are presented as descriptive statistics (Table 1). For quantitative data (chemical quality of the corn silages), an analysis of variance was performed to determine the effect of the collection point ( 1 to 5 ) along the silo. To determine the effect of collection type (W, or top, middle, base and composite), a Student's t-test or Wilcoxon test were performed according to the ShapiroWilk normality test. Specifically, Student t-tests were performed for OM, NDF, $\mathrm{ADF}$ and $\mathrm{CP}$, and Wilcoxon tests were performed for $\mathrm{pH}, \mathrm{TA}, \mathrm{DM}$ and ash. For the qualitative variables (shown in Table 1), a sample size reduction was performed through principal components analysis, in which the variables with collinearity were removed from the sample. For the analysis of the mean particle size, an analysis of variance was also performed. For all analyses, the statistical software R was used, with a significance level of 5\% (R DEVELOPMENT CORE TEAM, 2018).

\section{Results and Discussion}

\section{Silage management practices}

The management practices related to the ensiling processes and corn silage utilization of the 14 dairy farms are described in Table 1. Most of the dairy farms had up to 5 ha of corn crop destined for silage. In a study that had an objective of characterizing the properties of the southern region of Santa Catarina, Werncke et al. (2016) showed that the majority of the properties used family labor, and had on average 30 ha; for those who worked with dairy cattle, about 15.1 ha was destined for this activity, with an average of 3 ha for planted corn or sorghum for the production of silage.

In the choice of hybrid, most farmers decided to use dent kernel corn (64.29\%; Table 1). The dent texture of the corn grain negatively influences the digestibility of the starch present in the grain when consumed by the animal (CÔRREA et al., 2002). According to Hoffmann and Shaver (2011), the starch in the vitreous endosperm is more extensively encapsulated by prolamin-zein proteins; this leads to a poor attachment and slow potential degradation of the corn by rumen bacteria (ROMAGNOLO et al., 1994). One of the reasons for the lower use of softer texture hybrids (flint) is its low availability in the Brazilian market, together with the lack of information for producers regarding the differences in the availability of starch to the animals (SANTOS et al., 2016). For $50 \%$ of the farmers, the crop harvesting point was decided by analyzing the milkline. Changes in the amount of dry matter in the corn production cycle will influence the qualitative aspects of silage in relation to the amount of silage fiber and the energy density of the food (OLIVEIRA et al., 2007).

For the corn harvest, 35.71 and $28.57 \%$ of the farmers used harvest machines from farmer's associations and municipalities, respectively, and $35.71 \%$ had their own equipment; all the harvesters were pulled by tractors (Table 1). According to Bernardes et al. (2012), the use of this machinery 
is due to its lower cost; however, it can lead to a wide range in the size of the silage particles, and can increase the number of large particles, which can hamper the mass compaction process and lead to an increase of air entrainment in the silage material; when the silo is opened, this may result in molds entering the silage. As a cutting height, the highest percentage of farms were between 20 $35 \mathrm{~cm}$. The frequency of knife sharpening was twice per day (before and after cutting) (Table 1), which may have contributed to a uniform particle size, since no differences in particle size were observed during the unloading of the silos $(\mathrm{p}>0.05$, data not shown). According to Shinners (2003), not sharpening the knives causes lacerations of the plant, and ideally, the plant should be chopped. The silos were of the bunker model type, dug in the soil, and most were without any kind of revetment, with the silage deposited directly in the soil. This practice reduces costs in the construction of the silo. However, depositing silage directly on the soil can increase contamination by aerobic sporeformers, such as Clostridium spp. and Bacillus spp. (SLAGHUIS et al., 1997). Spores are unaffected by their passage through the gastrointestinal tract of the cow and are excreted in the feces (TE GIFFEL et al., 2002), which may be transferred to the milk via fecal contamination of the udder, making silage an important source of spores in milk (COOK; SANDEMAN, 2000). The silage ensiling and fermentation processes need to be controlled, and bunker silos without concrete should be avoided (BERNARDES; WEINBERG, 2013).

During silage compaction, the highest percentage of the producers sought to increase the weight of the tractors with the use of extra weights, and used ballasts in the wheels of the tractors (Table 1). One of the reasons for this is that, in addition to its dependence on particle size, a high silage density depends on factors such as the time of compaction with the tractor and the weight of the tractor at the time of compaction; the tractor's weight must be around $40 \%$ of the amount of the silage transported from the field to the silo per hour, so management need to be carried out adequately (MUCK; HOLMES, 2000).

To cover the silos, 13 dairy farmers used double-sided plastic films and only one used black plastic film. Double-sided plastic film has been recommended to maintain the fully anaerobic environment (AMARAL et al., 2014). Additionally, studies have recommended the use of oxygen barrier (OB) film to cover silos, once it was noted that it reduced oxygen permeability compared to standard film (BORREANI; TABACCO, 2008), resulting in lower counts of molds in the top layer of the silo (OROSZ et al., 2013), higher aerobic stability (more 2.5 days) and a $42 \%$ reduction in DM losses (WILKINSON; FENLON, 2013). According to Bernardes and Adesogan (2012), during the unloading of the silo, one of the ways to reduce aerobic deterioration is to ensure that the rate of silage removal is adequate for the production regions, at rates of 1.5 to $2.0 \mathrm{~m} /$ week. Most farmers $(57.14 \%)$ removed between $15-20 \mathrm{~cm} /$ day. This amount was divided over two removals per day; that is, they took one part in the morning and another in the afternoon. In this case, the farmers were above the recommended range. A recent study (OLIVEIRA et al., 2018) proposed a new methodology to assess the silo feed-out rate based on the daily amount of silage per square meter. According to the authors, a removal rate between $250-375 \mathrm{~kg}$ of silage $/ \mathrm{m}^{2} /$ day reduces the risk of spoilage of maize silages.

\section{Chemical and physical composition}

The total averages for the chemical and physical composition and particle size analyses for the two sampling methods, the "W" and the "composite" types (the mean of the top, middle and bottom), are shown in Table 2. The mean DM values, independent of the sampling method, were between 30.30 and $30.35 \%$; this is within the 30 to $37 \%$ ideal range for good fermentation of the silage and will result in a high-quality roughage, according to Nussio (1991) and Deminicis et al. (2009). 
Table 2. Mean values of the physical and chemical compositions of the corn silage from 14 dairy farms, evaluated during the unloading of commercial bunker silos, according to the sampling method (imaginary "W" in the silo panel, with 5 collection points corresponding to the points of the W vs. "combined", referring to the pool of samples made from the top, middle and bottom of the silo).

\begin{tabular}{|c|c|c|c|c|}
\hline Physical and chemical composition & Mean \pm SD & Minimum & Maximum & Median \\
\hline \multicolumn{5}{|l|}{ Dry matter (DM), \% } \\
\hline $\mathrm{W}$ & $30.30 \pm 3.89$ & 20.83 & 37.18 & 30.89 \\
\hline Combined & $30.35 \pm 4.03$ & 17.61 & 38.98 & 30.15 \\
\hline \multicolumn{5}{|l|}{ Ash, $\%$ of DM } \\
\hline $\mathrm{W}$ & $4.92 \pm 1.23$ & 2.60 & 7.36 & 4.85 \\
\hline Combined & $4.64 \pm 1.19$ & 2.13 & 9.96 & 4.66 \\
\hline \multicolumn{5}{|l|}{ Organic matter, $\%$ of DM } \\
\hline $\mathrm{W}$ & $25.37 \pm 4.22$ & 15.73 & 34.38 & 26.12 \\
\hline Combined & $25.70 \pm 4.13$ & 12.70 & 35.50 & 26.06 \\
\hline \multicolumn{5}{|l|}{ Crude protein, $\%$ of DM } \\
\hline W & $7.90 \pm 1.12$ & 4.48 & 10.58 & 8.04 \\
\hline Combined & $7.98 \pm 1.40$ & 3.75 & 14.44 & 7.91 \\
\hline \multicolumn{5}{|l|}{ Neutral detergent fiber, $\%$ of DM } \\
\hline $\mathrm{W}$ & $45.4 \pm 9.89$ & 27.54 & 81.01 & 43.65 \\
\hline Combined & $45.1 \pm 10.41$ & 24.15 & 73.85 & 42.90 \\
\hline \multicolumn{5}{|l|}{ Acid detergent fiber, $\%$ of DM } \\
\hline $\mathrm{W}$ & $26.7 \pm 12.13$ & 11.77 & 81.68 & 23.64 \\
\hline Combined & $24.2 \pm 7.56$ & 11.08 & 58.19 & 22.70 \\
\hline \multicolumn{5}{|l|}{$\mathrm{pH}$} \\
\hline W & $3.74 \pm 0.40$ & 3.08 & 6.03 & 3.63 \\
\hline Combined & $3.68 \pm 0.41$ & 3.07 & 6.48 & 3.60 \\
\hline \multicolumn{5}{|l|}{ Titratable acidity (mL NaOH to reach $\mathrm{pH} 7)$} \\
\hline W & $24.21 \pm 9.13$ & 4.0 & 48.00 & 25.65 \\
\hline Combined & $25.60 \pm 9.16$ & 3.0 & 49.35 & 26.88 \\
\hline \multicolumn{5}{|l|}{ Particle size distribution } \\
\hline \multicolumn{5}{|l|}{ W } \\
\hline$>38 \mathrm{~mm}$ & $1.3 \pm 1.77$ & 0.0 & 6.7 & 0 \\
\hline $38-19 \mathrm{~mm}$ & $4.5 \pm 3.74$ & 0.0 & 17.9 & 4.6 \\
\hline $19-8 \mathrm{~mm}$ & $61.1 \pm 10.53$ & 40.4 & 86.0 & 62 \\
\hline Bottom $<8 \mathrm{~mm}$ & $33.2 \pm 10.03$ & 12.8 & 53.8 & 31.1 \\
\hline \multicolumn{5}{|l|}{ Combined } \\
\hline$>38 \mathrm{~mm}$ & $1.5 \pm 0.30$ & 0.0 & 5.4 & 0.3 \\
\hline $38-19 \mathrm{~mm}$ & $4.0 \pm 3.22$ & 0.0 & 9.9 & 4.3 \\
\hline $19-8 \mathrm{~mm}$ & $61.1 \pm 9.97$ & 42.8 & 86.2 & 61.0 \\
\hline Bottom $<8 \mathrm{~mm}$ & $33.7 \pm 9.47$ & 11.9 & 52.6 & 32.8 \\
\hline
\end{tabular}

The mean values for ashes had lower results compared to those of Possenti et al. (2005), who found values of $5.8 \%$ in corn silages. For the $\mathrm{pH}$ values, the results were similar to those of Oliveira et al. (2010), who found a $\mathrm{pH}$ of 3.8. According to Wilkinson et al. (2003), $\mathrm{pH} 4$ describes a wellpreserved silage. In terms of the neutral detergent fiber (NDF) and acid detergent fiber (ADF), mean values were similar to those of Jobim et al. (2010), who found values of $45.9 \%$ and $27.5 \%$ of NDF and ADF, respectively, as were the values of crude protein $(7.5 \%)$, which fit within the ideal values for corn silage ( 7 to $8 \%$ ). 
The mean values of the particles, according to Tables 2 and 3, are different from those recommended by Lammers et al. (1996), who noted that the percentage of the material with diameters greater than $19 \mathrm{~mm}$ (sieve 1), intermediate diameters of $8 \mathrm{~mm}$ (sieve 2) and $1.18 \mathrm{~mm}$ (sieve 3), and diameters less than $1.18 \mathrm{~mm}$ should be $3-8 \%$, 45$65 \%, 30-40 \%$ and less than 5\%, respectively. This demonstrates that the values found in this study encompassed a larger amount of smaller particles than is recommended. When particle size is reduced, the cellular rupture in the forage increases, and consequently, cellular content extravasation occurs (KRAUS et al., 1997). According to McDonald et al. (1991), particle sizes less than 20-30 mm relative to the silage may favor a greater amount of soluble carbohydrates in the silage, and thereby increase lactic acid bacteria growth.

Table 3. Mean values (\%) for the particle size of the corn silage of commercial bunker silos, according to the different sampling types (imaginary "W" in the silo panel, with 5 collection points corresponding to the points of the W; "strata" and "combined" refer to the pool of samples made from the top, middle and bottom of the silo).

\begin{tabular}{cccccc}
\hline & \multicolumn{5}{c}{ Sample collection location on the silo panel } \\
\hline Particle size & $\mathrm{W}$ & Top & Middle & Bottom & Combined \\
\hline Sieve 1 $(>38 \mathrm{~mm})$ & $1.2^{\mathrm{a}} \pm 1.87$ & $1.3^{\mathrm{a}} \pm 1.77$ & $1.1^{\mathrm{a}} \pm 1.73$ & $1.1^{\mathrm{a}} \pm 1.71$ & $1.1^{\mathrm{a}} \pm 1.57$ \\
Sieve 2 $(38-19 \mathrm{~mm})$ & $4.4^{\mathrm{b}} \pm 3.98$ & $4.6^{\mathrm{b}} \pm 4.07$ & $3.7^{\mathrm{a}} \pm 3.74$ & $3.8^{\mathrm{a}} \pm 3.87$ & $2.6^{\mathrm{b}} \pm 2.91$ \\
Sieve 3 $(19-8 \mathrm{~mm})$ & $61.6^{\mathrm{a}} \pm 10.50$ & $60.1^{\mathrm{a}} \pm 11.15$ & $60.9^{\mathrm{a}} \pm 9.95$ & $62.0^{\mathrm{a}} \pm 10.81$ & $61.2^{\mathrm{a}} \pm 9.87$ \\
Sieve 4 $(<8 \mathrm{~mm})$ & $32.7^{\mathrm{a}} \pm 9.97$ & $33.9^{\mathrm{a}} \pm 10.74$ & $34.2^{\mathrm{a}} \pm 9.47$ & $32.9^{\mathrm{a}} \pm 10.62$ & $33.4^{\mathrm{a}} \pm 9.29$ \\
\hline
\end{tabular}

In relation to the silage sampling method on the silo panel, there were no significant differences in relation to $\mathrm{DM}$, ash, $\mathrm{OM}, \mathrm{CP}, \mathrm{NDF}$, and $\mathrm{ADF}$ $(p>0.05)$ (Table 4$)$. For the analysis of $\mathrm{pH}$ and TA, the type of collection in the silo panel showed statistical differences $(\mathrm{p}<0.05)$. The $\mathrm{pH}$ in the top collection was the highest (3.8), although it still remained within the level that is considered ideal. Winckler (2015) also found a difference in $\mathrm{pH}$ values between the top and middle of the silo, and verified that the $\mathrm{pH}$ at the top was superior to that of the middle. Oxygen deposition in the silo affects the quality of the silage, because during silage storage, the upper layer stays in contact with oxygen for a longer time, resulting in a greater difficulty in lowering the $\mathrm{pH}$ (SAVOIE; JOFRIET, 2003). Accordingly, the TA was higher in samples collected at the silo base $(p<0.05)$, with values of 28.6. Jobim et al. (2007) cite that TA is a more adequate concept to explain the silage quality than the $\mathrm{pH}$, because the TA is related to the production of lactic acid produced in the silage, whereas the $\mathrm{pH}$ is related to all the acids that are produced. 
Table 4. Dry matter (DM), ash, organic matter (OM), crude protein (CP), neutral detergent fiber (NDF), acid detergent fiber (ADF), $\mathrm{pH}$ and titratable acidity (TA) of the corn silage from the different types of sampling, according to the sampling method (imaginary "W" in the silo panel, with 5 collection points corresponding to the points of the W; "strata" and "combined", referring to the pool of samples made from the top, middle and bottom of the silo).

\begin{tabular}{cccccc}
\hline & \multicolumn{5}{c}{ Sample collection location on the silo panel } \\
\cline { 2 - 5 } Content & $\mathrm{W}$ & Top & Middle & Bottom & Combined \\
\hline DM, \% & $30.2^{\mathrm{b}} \pm 3.88$ & $30.9^{\mathrm{b}} \pm 4.20$ & $30.4^{\mathrm{b}} \pm 4.11$ & $29.6^{\mathrm{a}} \pm 3.71$ & $30.3^{\mathrm{ab}} \pm 3.65$ \\
$\mathrm{Ash}^{1}$ & $4.9^{\mathrm{c}} \pm 1.23$ & $4.7^{\mathrm{bc}} \pm 1.32$ & $4.5^{\mathrm{a}} \pm 1.14$ & $4.6^{\mathrm{ab}} \pm 1.09$ & $4.6^{\mathrm{ac}} \pm 1.03$ \\
$\mathrm{OM}^{1}$ & $25.3^{\mathrm{ab}} \pm 4.21$ & $26.1^{\mathrm{c}} \pm 4.52$ & $25.9^{\mathrm{b}} \pm 4.07$ & $25.0^{\mathrm{a}} \pm 3.75$ & $25.7^{\mathrm{c}} \pm 3.73$ \\
$\mathrm{CP}^{1}$ & $7.9^{\mathrm{a}} \pm 1.11$ & $8.0^{\mathrm{a}} \pm 1.52$ & $7.9^{\mathrm{a}} \pm 1.23$ & $7.9^{\mathrm{a}} \pm 1.43$ & $7.9^{\mathrm{a}} \pm 1.00$ \\
$\mathrm{NDF}^{1}$ & $45.4^{\mathrm{a}} \pm 9.97$ & $46.2^{\mathrm{a}} \pm 10.30$ & $44.5^{\mathrm{a}} \pm 10.89$ & $44.6^{\mathrm{a}} \pm 10.17$ & $45.15^{\mathrm{a}} \pm 7.78$ \\
$\mathrm{ADF}^{1}$ & $26.7^{\mathrm{a}} \pm 12.25$ & $25.3^{\mathrm{a}} \pm 8.01$ & $24.2^{\mathrm{ab}} \pm 8.11$ & $23.1^{\mathrm{b}} \pm 6.46$ & $24.2^{\mathrm{ab}} \pm 4.76$ \\
$\mathrm{pH}^{\mathrm{b}}$ & $3.7^{\mathrm{b}} \pm 0.40$ & $3.8^{\mathrm{c}} \pm 0.52$ & $3.6^{\mathrm{a}} \pm 0.30$ & $3.5^{\mathrm{a}} \pm 0.32$ & $3.6^{\mathrm{b}} \pm 3.60$ \\
$\mathrm{TA}^{2}$ & $24.2^{\mathrm{ab}} \pm 9.13$ & $22.2^{\mathrm{a}} \pm 9.21$ & $25.9^{\mathrm{b}} \pm 8.36$ & $28.6^{\mathrm{c}} \pm 8.85$ & $25.6^{\mathrm{b}} \pm 7.31$ \\
\hline
\end{tabular}

${ }^{1} \%$ of $\mathrm{DM} ;{ }^{2} \mathrm{~mL}$ of $\mathrm{NaOH} 0.1 \mathrm{~N}$ to reach a $\mathrm{pH}$ of 7.0 .

Means followed by different lowercase letters within a line differ by Tukey's test $(\mathrm{p}<0.05)$.

Table 5 shows the chemical and physical analysis results of the corn silages during the unloading of the commercial bunker silos. The levels of DM, ash, OM, CP, NDF, ADF, pH and TA did not differ statistically between the sampling points $(\mathrm{p}>0.05)$, demonstrating a stable composition during the silage usage. Neumann et al. (2007) verified that, during the unloading of silos, no variable influenced the DM, $\mathrm{CP}$ or NDF contents of corn silage. The authors also emphasized the existence of a few studies that took the changes due to the management of the unloading of the silo into account, such as the air intake that occurs in the silo, which leads to oxidation resulting from the activity of the microorganisms.

Table 5. Dry matter (DM), ash, organic matter (OM), crude protein (CP), neutral detergent fiber (NDF), acid detergent fiber (ADF), $\mathrm{pH}$ and titratable acidity (TA) of the corn silage according to the different sampling types (imaginary "W" in the silo panel, with 5 collection points corresponding to the points of the W; "strata" and "combined", referring to the pool of samples made from the top, middle and bottom of the silo) and during the unloading of bunker silos (5 collection points).

\begin{tabular}{ccccccc}
\hline \multirow{2}{*}{ Content } & $\begin{array}{c}\text { Collection } \\
\text { point }\end{array}$ & \multicolumn{4}{c}{ Sample collection location on the silo panel } & \multirow{2}{*}{ Combined } \\
\cline { 3 - 6 } & 1 & $31.6^{\mathrm{a}} \pm 2.89$ & $31.4^{\mathrm{a}} \pm 3.54$ & $31.4^{\mathrm{a}} \pm 3.30$ & $30.2^{\mathrm{a}} \pm 3.23$ & $31.0^{\mathrm{a}} \pm 3.01$ \\
& 2 & $30.5^{\mathrm{a}} \pm 3.15$ & $31.3^{\mathrm{a}} \pm 3.03$ & $31.3^{\mathrm{a}} \pm 3.31$ & $19.8^{\mathrm{a}} \pm 2.87$ & $30.8^{\mathrm{a}} \pm 3.11$ \\
& 3 & $31.2^{\mathrm{a}} \pm 4.02$ & $32.4^{\mathrm{a}} \pm 4.47$ & $30.9^{\mathrm{a}} \pm 3.93$ & $30.8^{\mathrm{a}} \pm 3.88$ & $31.7^{\mathrm{a}} \pm 3.47$ \\
& 4 & $31.0^{\mathrm{a}} \pm 2.22$ & $31.3^{\mathrm{a}} \pm 3.00$ & $30.7^{\mathrm{a}} \pm 3.08$ & $29.4^{\mathrm{a}} \pm 3.08$ & $30.1^{\mathrm{a}} \pm 3.26$ \\
$\mathrm{DM}^{1}$ & 5 & $29.1^{\mathrm{a}} \pm 4.39$ & $28.8^{\mathrm{a}} \pm 4.48$ & $29.5^{\mathrm{a}} \pm 4.37$ & $27.4^{\mathrm{a}} \pm 3.59$ & $28.5^{\mathrm{a}} \pm 4.37$ \\
& 1 & $4.8^{\mathrm{a}} \pm 1.17$ & $4.6^{\mathrm{a}} \pm 1.04$ & $4.5^{\mathrm{a}} \pm 0.96$ & $4.2^{\mathrm{a}} \pm 0.94$ & $4.6^{\mathrm{a}} \pm 0.98$ \\
& 2 & $5.0 \mathrm{a} \pm 1.45$ & $4.7^{\mathrm{a}} \pm 1.14$ & $4.2^{\mathrm{a}} \pm 1.09$ & $4.2^{\mathrm{a}} \pm 1.13$ & $4.4^{\mathrm{a}} \pm 1.11$ \\
& 3 & $4.7^{\mathrm{a}} \pm 1.09$ & $4.4^{\mathrm{a}} \pm 1.16$ & $4.3^{\mathrm{a}} \pm 1.05$ & $4.4^{\mathrm{a}} \pm 0.71$ & $4.62^{\mathrm{a}} \pm 1.01$ \\
& 4 & $4.9^{\mathrm{a}} \pm 1.09$ & $4.7^{\mathrm{a}} \pm 1.18$ & $4.4^{\mathrm{a}} \pm 1.19$ & $4.1^{\mathrm{a}} \pm 1.21$ & $4.5^{\mathrm{a}} \pm 0.92$ \\
$\mathrm{Ash}^{2}$ & 5 & $5.2^{\mathrm{a}} \pm 1.15$ & $4.5^{\mathrm{a}} \pm 0.89$ & $4.6^{\mathrm{a}} \pm 1.12$ & $5.0^{\mathrm{a}} \pm 0.93$ & $4.5^{\mathrm{a}} \pm 0.74$
\end{tabular}


continuation

\begin{tabular}{|c|c|c|c|c|c|c|}
\hline & 1 & $26.6^{\mathrm{a}} \pm 3.07$ & $25.6^{\mathrm{a}} \pm 3.20$ & $26.9^{\mathrm{a}} \pm 3.30$ & $25.8^{\mathrm{a}} \pm 3.28$ & $26.1^{\mathrm{a}} \pm 3.04$ \\
\hline & 2 & $25.6^{\mathrm{a}} \pm 3.64$ & $27.5^{\mathrm{a}} \pm 2.95$ & $26.1^{\mathrm{a}} \pm 3.21$ & $25.6^{\mathrm{a}} \pm 3.34$ & $25.9^{\mathrm{a}} \pm 3.00$ \\
\hline & 3 & $26.9^{\mathrm{a}} \pm 3.31$ & $27.7^{\mathrm{a}} \pm 3.72$ & $25.6^{\mathrm{a}} \pm 2.94$ & $27.3^{\mathrm{a}} \pm 2.61$ & $26.2^{\mathrm{a}} \pm 3.27$ \\
\hline & 4 & $25.5^{\mathrm{a}} \pm 3.62$ & $25.4^{\mathrm{a}} \pm 3.13$ & $25.4^{\mathrm{a}} \pm 2.70$ & $24.9^{\mathrm{a}} \pm 3.45$ & $24.3^{\mathrm{a}} \pm 2.84$ \\
\hline \multirow[t]{5}{*}{$\mathrm{OM}^{2}$} & 5 & $23.4^{\mathrm{a}} \pm 4.16$ & $25.1^{\mathrm{a}} \pm 3.48$ & $24.1^{\mathrm{a}} \pm 3.93$ & $23.1^{\mathrm{a}} \pm 3.65$ & $23.6^{\mathrm{a}} \pm 4.37$ \\
\hline & 1 & $8.3^{\mathrm{a}} \pm 1.08$ & $7.9^{\mathrm{a}} \pm 1.35$ & $8.0^{\mathrm{a}} \pm 1.15$ & $8.0^{\mathrm{a}} \pm 0.95$ & $8.1^{\mathrm{a}} \pm 0.98$ \\
\hline & 2 & $7.9^{\mathrm{a}} \pm 0.97$ & $8.5^{\mathrm{a}} \pm 1.41$ & $7.7^{\mathrm{a}} \pm 0.81$ & $7.6^{\mathrm{a}} \pm 0.96$ & $8.1^{\mathrm{a}} \pm 1.12$ \\
\hline & 3 & $7.8^{\mathrm{a}} \pm 1.08$ & $7.6^{\mathrm{a}} \pm 0.94$ & $8.2^{\mathrm{a}} \pm 1.04$ & $7.5^{\mathrm{a}} \pm 0.97$ & $7.9^{\mathrm{a}} \pm 0.84$ \\
\hline & 4 & $7.7^{\mathrm{a}} \pm 0.97$ & $7.4^{\mathrm{a}} \pm 1.27$ & $7.9^{\mathrm{a}} \pm 0.89$ & $7.6^{\mathrm{a}} \pm 0.70$ & $7.9^{\mathrm{a}} \pm 0.88$ \\
\hline \multirow[t]{5}{*}{$\mathrm{CP}^{2}$} & 5 & $7.8^{\mathrm{a}} \pm 1.14$ & $7.9^{\mathrm{a}} \pm 0.89$ & $7.7^{\mathrm{a}} \pm 1.20$ & $7.8^{\mathrm{a}} \pm 0.88$ & $7.7^{\mathrm{a}} \pm 0.93$ \\
\hline & 1 & $44.5^{\mathrm{a}} \pm 8.23$ & $46.8^{a} \pm 10.13$ & $45.7^{\mathrm{a}} \pm 9.33$ & $44.3^{\mathrm{a}} \pm 10.66$ & $45.6^{\mathrm{a}} \pm 8.03$ \\
\hline & 2 & $46.6^{\mathrm{a}} \pm 11.44$ & $43.9 \mathrm{a} \pm 9.90$ & $45.3^{\mathrm{a}} \pm 10.64$ & $47.7^{\mathrm{a}} \pm 10.92$ & $45.6^{\mathrm{a}} \pm 6.99$ \\
\hline & 3 & $40.8^{\mathrm{a}} \pm 5.33$ & $47.6 \mathrm{a} \pm 11.74$ & $43.5^{\mathrm{a}} \pm 12.27$ & $45.3^{\mathrm{a}} \pm 12.30$ & $45.5^{\mathrm{a}} \pm 8.79$ \\
\hline & 4 & $47.3^{\mathrm{a}} \pm 11.31$ & $44.5 \mathrm{a} \pm 10.5$ & $42.1^{\mathrm{a}} \pm 8.27$ & $40.5^{\mathrm{a}} \pm 7.94$ & $42.4^{\mathrm{a}} \pm 6.97$ \\
\hline \multirow[t]{5}{*}{$\mathrm{NDF}^{2}$} & 5 & $47.8^{\mathrm{a}} \pm 11.72$ & $48.5^{\mathrm{a}} \pm 9.87$ & $45.9^{\mathrm{a}} \pm 14.07$ & $45.3^{\mathrm{a}} \pm 8.51$ & $46.5^{\mathrm{a}} \pm 8.42$ \\
\hline & 1 & $28.5^{\mathrm{a}} \pm 18.42$ & $26.3^{\mathrm{a}} \pm 10.55$ & $25.2^{\mathrm{a}} \pm 5.40$ & $21.8^{\mathrm{a}} \pm 3.70$ & $24.5^{\mathrm{a}} \pm 5.39$ \\
\hline & 2 & $27.8^{\mathrm{a}} \pm 11.74$ & $22.1^{\mathrm{a}} \pm 5.73$ & $21.1^{\mathrm{a}} \pm 3.11$ & $27.8^{\mathrm{a}} \pm 11.01$ & $23.7^{\mathrm{a}} \pm 4.56$ \\
\hline & 3 & $21.8^{\mathrm{a}} \pm 4.33$ & $26.1^{\mathrm{a}} \pm 6.57$ & $23.5^{a} \pm 10.25$ & $22.3^{\mathrm{a}} \pm 5.16$ & $24.0^{\mathrm{a}} \pm 4.32$ \\
\hline & 4 & $28.5^{\mathrm{a}} \pm 14.22$ & $25.0^{\mathrm{a}} \pm 9.47$ & $25.7^{\mathrm{a}} \pm 9.51$ & $21.2^{\mathrm{a}} \pm 3.55$ & $24.0^{\mathrm{a}} \pm 4.98$ \\
\hline \multirow[t]{3}{*}{$\mathrm{ADF}^{2}$} & 5 & $26.8^{\mathrm{a}} \pm 7.78$ & $26.9^{\mathrm{a}} \pm 6.95$ & $25.4^{\mathrm{a}} \pm 9.93$ & $22.6^{\mathrm{a}} \pm 4.09$ & $25.0^{\mathrm{a}} \pm 5.08$ \\
\hline & 1 & $3.9^{\mathrm{a}} \pm 0.64$ & $3.8^{\mathrm{a}} \pm 0.18$ & $3.7^{\mathrm{a}} \pm 0.24$ & $3.6^{\mathrm{a}} \pm 0.23$ & $3.7^{\mathrm{a}} \pm 0.46$ \\
\hline & 2 & $3.7^{\mathrm{ab}} \pm 0.45$ & $3.7^{\mathrm{a}} \pm 0.37$ & $3.5 \mathrm{a} \pm 0.32$ & $3.5^{\mathrm{ab}} \pm 0.16$ & $3.6^{\mathrm{a} b} \pm 0.79$ \\
\hline \multirow[t]{5}{*}{$\mathrm{pH}$} & 3 & $3.6^{\mathrm{ab}} \pm 0.23$ & $3.7 \mathrm{a} \pm 0.17$ & $3.5^{\mathrm{a}} \pm 0.22$ & $3.5^{\mathrm{ab}} \pm 0.17$ & $3.6^{\mathrm{ab}} \pm 0.54$ \\
\hline & 4 & $3.6^{\mathrm{ab}} \pm 0.23$ & $3.8^{\mathrm{a}} \pm 0.16$ & $3.6^{\mathrm{a}} \pm 0.19$ & $3.6^{\mathrm{ab}} \pm 0.19$ & $3.6^{\mathrm{ab}} \pm 0.62$ \\
\hline & 5 & $3.6^{\mathrm{b}} \pm 0.24$ & $3.8^{\mathrm{a}} \pm 0.20$ & $3.6^{\mathrm{a}} \pm 0.19$ & $3.4^{b} \pm 0.16$ & $3.5^{\mathrm{a}} \pm 0.63$ \\
\hline & 1 & $18.1^{\mathrm{b}} \pm 8.36$ & $20.4^{a} \pm 8.28$ & $25.5^{\mathrm{a}} \pm 8.75$ & $27.5^{\mathrm{a}} \pm 7.80$ & $25.0^{\mathrm{ab}} \pm 7.24$ \\
\hline & 2 & $25.8^{\mathrm{ab}} \pm 7.17$ & $24.7^{\mathrm{a}} \pm 8.38$ & $28.6^{\mathrm{a}} \pm 4.82$ & $29.0^{\mathrm{a}} \pm 8.91$ & $27.4^{\mathrm{a}} \pm 5.92$ \\
\hline \multirow[t]{3}{*}{$\mathrm{TA}^{3}$} & 3 & $25.8^{\mathrm{ab}} \pm 9.33$ & $20.5^{\mathrm{a}} \pm 8.27$ & $28.4^{\mathrm{a}} \pm 6.49$ & $29.8^{\mathrm{a}} \pm 8.63$ & $25.3^{\mathrm{a}} \pm 6.51$ \\
\hline & 4 & $27.2^{\mathrm{a}} \pm 5.73$ & $23.8^{\mathrm{a}} \pm 10.10$ & $29.1^{\mathrm{a}} \pm 5.84$ & $28.7^{\mathrm{a}} \pm 5.23$ & $26.8^{\mathrm{a}} \pm 5.74$ \\
\hline & 5 & $20.2^{\mathrm{ab}} \pm 8.47$ & $21.6^{\mathrm{a}} \pm 9.14$ & $21.8^{\mathrm{a}} \pm 8.72$ & $29.9^{\mathrm{a}} \pm 7.85$ & $25.1^{\mathrm{a}} \pm 6.25$ \\
\hline
\end{tabular}

$1 \% ;{ }^{2 \%} \%$ of $\mathrm{DM} ;{ }^{3} \mathrm{~mL}$ of $\mathrm{NaOH} 0.1 \mathrm{~N}$ to reach $\mathrm{pH} 7.0$.

Means followed by different lowercase letters in the same column differ by Tukey's test $(\mathrm{p}<0.05)$.

Junges (2014) evaluated silo unloading times, comparing the digestibility of the top and bottom silage for dairy cows, and found significant differences in the digestibility of DM and NDF $(\mathrm{p}<0.01)$, with DM values of 70.42 and $73.40 \%$ for the top and bottom, and NDF values of 47.78 and $54.97 \%$ for the top and bottom, respectively; the other variables did not have significant differences.
The same author also verified that diets with the silage from the base had a higher $(\mathrm{p}<0.01)$ nutritive value than diets with the top silage, due to the supply from the base having higher levels of carbohydrates; however, Junges concluded that the silo discharge did not affect the quality of the silage, although the sample sites had differences in the composition of the silage. 


\section{Principal components analysis}

The 11 representative variables, arranged in the Cartesian plane with their influence on the two major dimensions, are presented in Figure 2. Principal Component 1 corresponds to $29.1 \%$ of the variability, and Principal Component 2, to $25.5 \%$ of the variability in the data. That is, the analysis of the main components represented by the two dimensions is responsible for $54.6 \%$ of the variance in the analyzed data. The variables corn variety $(15.49 \%)$, frequency of silage removal (14.65\%), and the harvester owner $(12.58 \%)$ were those that presented the greatest influence on the variability of the data belonging to Principal Component 1 . The variables that had the greatest influence on the variability of the data in Principal Component 2 were the use of double-sided plastic film (20.09\%), silo capacity $(17.88 \%)$ and whether the farmer followed any hybrid technical recommendations $(17.35 \%)$. It is worth mentioning that the variables that had an influence on each main component are a result of the dimensional reduction of all variables; that is, only 11 remained in the data file.

According to the data analysis, the hybrid (corn variety) was the factor that had the greatest effect on the variability of the quality of corn silage (Figure 2). We hypothesize that good silage management practices may have been conducted on all farms, which resulted in greater variation due to the corn hybrid. Another qualitative variable that had relevance was whether the farm followed the planting recommendations of the hybrid; thus, this was still related to the hybrid itself. On the other hand, in Principal Component 2, the greatest influence on quality was the use of double-sided plastic film, which is related to silage storage. Double sealing did not affect the silage nutritional composition, but increased dry matter recovery (88.79\% vs. $85.64 \%)$ and in vitro neutral detergent fiber digestibility $(33.04 \%$ vs. $24.6 \%)$, when compared to the conventional version (NEUMANN et al., 2017).

Figure 2. Projection of the effects of each variable on each of the first and second main components related to the qualitative monitoring of corn silage during the unloading of commercial bunker silos.

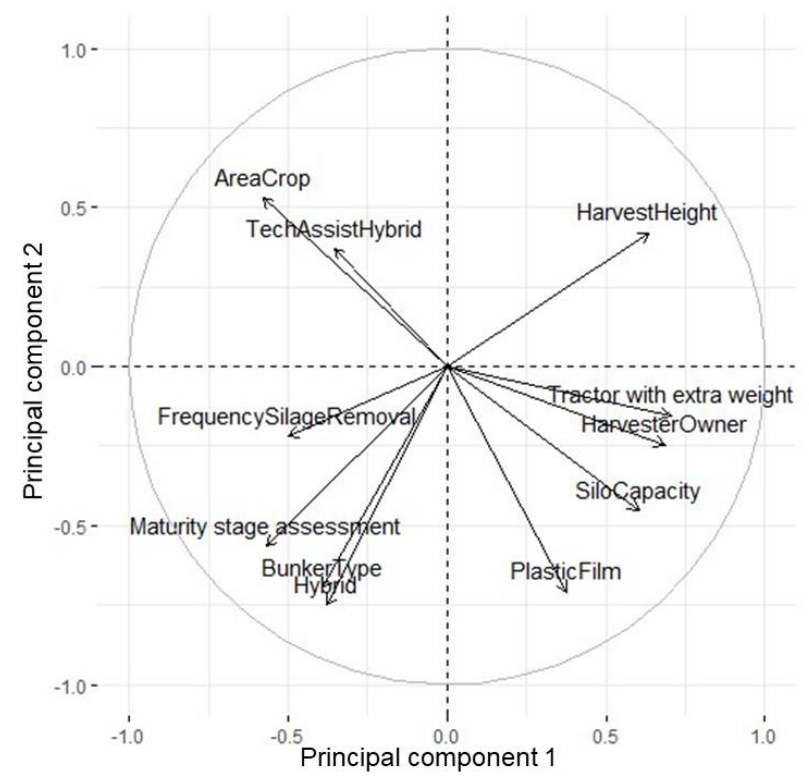

Legend: AreaCrop: area (ha) used for crop; TechAssistHybrid: whether the farmer follows technical assistance for hybrid planting; FrequencySilageRemoval: the frequency of silage removal on the dairy farms (1 to 3 times per day); Hybrid (dent, soft or flint); PlasticFilm (presence or absence of plastic film on the silo); SiloCapacity (strata: $>50 \mathrm{t}, 50-150 \mathrm{t}, 150-250 \mathrm{t}$ and $>250 \mathrm{t}$ ); HarvesterOwner (owner of the harvester: farmer's association, municipality or particular). 


\section{Conclusions}

Dairy farmers appeared to apply good practices in the process of making corn silage in the western region of Santa Catarina. As a consequence, the corn silage presented a homogeneous quality throughout the silos. Either "W" or layer collections can be used to sample corn silage.

\section{References}

AMARAL, R. C. do; SANTOS, M. C.; DANIEL, J. L. P.; SÁ, A. de; BISPO, A. W.; CABEZAS-GARCIA, E. H.; BERNARDES, T. F.; NUSSIO, L. G. The influence of covering methods on the nutritive value of corn silage for lactating dairy cows. Revista Brasileira de Zootecnia, Viçosa, MG, v. 43, n. 9, p. 471-478, 2014. DOI: 10.1590/ S1516-35982014000900003

ASSOCIATION OF OFFICIAL ANALYTICAL CHEMISTS - AOAC. Official methods of analysis. $15^{\text {th }}$ ed. Agricultural Chemical; Contaminants; Drugs. Arlington: AOAC Inc., 1990. v. 1, 768 p.

ASSOCIATION OF OFFICIAL ANALYTICAL CHEMISTS - AOAC. Official methods of analysis. $16^{\text {th }}$ ed. 3rd rev. Gaitherburg: AOAC International. 1997.

ASSOCIATION OF OFFICIAL ANALYTICAL CHEMISTS - AOAC. Official methods of analysis. 17 $7^{\text {th }}$ ed. Gaithersburg: AOAC International, 2000. v. I and II.

BERNARDES, T. F.; ADESOGAN, A. T. Aerobic deterioration of silages in warm. In: INTERNATIONAL SILAGE CONFERENCE, 16., 2016, Helsinki. Proceedings... Hameenlinna: MMT Agrifood Research Finland, University of Helsinki, 2012. p. 322-323.

BERNARDES, T. F.; CARVALHO, I. Q.; SILVA, N. C. A. Snapshot of maize silage quality on dairy farms in South Brazil. In: INTERNATIONAL SILAGE CONFERENCE, 2012, Hämeenlinna. Proceedings... Hämeenlinna: University of Helsinki, 2012. p. 322-323.

BERNARDES, T. F.; CHIZZOTTI, F. H. M. Technological innovations in silage production and utilization. Revista Brasileira de Saúde e Produção Animal, Lavras, v. 13, n. 3, p. 629-641, 2012. DOI: 10.1590/S1519-99402012000300004

BERNARDES, T. F.; RÊGO, A. C. do. Study on the practices of silage production and utilization on Brazilian dairy farms. Journal of Dairy Science, Champaign, v. 97, n. 3 , p. $1852-1861$, 2014. DOI: $10.3168 /$ jds.2013-7181
BERNARDES, T. F.; WEINBERG, Z. Aspectos associados ao manejo da ensilagem. In: REIS, R. A.; BERNARDES, T. F.; SIQUEIRA, G. R. Forragicultura: ciência, tecnologia e gestão dos recursos forrageiros. Jaboticabal: Gráfica Multipress, 2013. cap. 42, p. 671680.

BORREANI, G.; TABACCO, E. Low permeability to oxygen of a new barrier film prevents butyric acid bacteria spore formation in farm corn silage. Journal of Dairy Science, Champaign, v. 91, n. 11, p. 4272-4281, 2008. DOI: $10.3168 /$ jds.2008-1151

COOK, G. M.; SANDEMAN, R. M. Sources and characterisation of spore-forming bacteria in raw milk. Australian Journal of Dairy Technology, Melbourne, v. 55, n. 3, p. 119-126, 2000.

CÔRREA, C. E. S.; SHAVER, R. D.; PEREIRA, M. N.; LAUER, J. G.; KOHN, K. Relationship between corn vitreousness and ruminal in situ starch degradability. Journal of Dairy Science, Champaign, v. 85, n. 11, p. 30083012, 2002. DOI: $10.3168 /$ jds.S0022-0302(02)74386-5

DEMINICIS, B. B.; VIEIRA, H. D.; JARDIM, J. G.; ARAÚJO, S. A. C.; CHAMBELA NETO, A.; OLIVEIRA, V. C.; LIMA, E. S. Silagem de milho: características agronômicas e considerações. Revista Eletrônica de Veterinária, Andalucía, v. 10, n. 2, p. 1-18, 2009.

HOFFMAN, P. C.; SHAVER, R. D. The nutritional chemistry of dry and high moisture corn. In: ANNUAL SOUTHWEST NUTRITION AND MANAGEMENT CONFERENCE, 26, 2011, Arizona. Proceedings. Arizona: The University of Arizona Department of Animal Sciences. p. 12-23.

JOBIM, C. C.; CALIXTO JUNIOR, M.; BUMBIERIS JUNOR, V. H.; OLIVEIRA, F. C. L. Chemical composition and quality of conservation of corn (Zea mays L.) grain silages with different levels of soy grains (Glycine max Merril). Semina: Ciências Agrárias, Londrina, v. 31, n. 3, p. 773-782, 2010. DOI: 10.5433/1679-0359.2010v31n3p773

JOBIM, C. C.; NUSSIO, L. G.; REIS, R. A.; SCHMIDT, P. Avanços metodológicos na avaliação da qualidade da forragem conservada. Revista Brasileira de Zootecnia, Viçosa, MG, v. 36, p. 101-119, 2007. Suplemento Especial. DOI: 10.1590/S1516-35982007001000013

JUNGES, D. Aditivo microbiano na silagem de milho em diferentes tempos de armazenamento e avaliação da estabilidade aeróbia por termografia em infravermelho. 2010. Dissertação (Mestrado em Ciências Veterinárias) Universidade Federal do Paraná, Curitiba. 
JUNGES, D. Tempo de armazenamento e manejo do painel no valor nutritivo de silagens de milho. 2014. Tese (Doutorado em Ciência Animal e Pastagens) - Escola Superior de Agricultura Luiz de Queiroz - Universidade de São Paulo, Piracicaba.

KOMAREK, A. R. A filter bag procedure for improved efficiency of fiber analysis. Journal of Dairy Science, Champaign, v. 76, p. 250-259, 1993. Supplement 1.

KRAUS, T. J.; KOEGER, R. G.; STRAUB, R. J.; SHINNERS, K. J. Leachate conductivity as an index for quantifying level of forage conditioning. In: ASAE ANNUAL INTERNATIONAL MEETING, 1997, Minneapolis. Proceedings... Minneapolis: ASAE, 1997. p. 1-12.

LAMMERS, B. P.; BUCKMASTER, D. R.; HEINRICHS, J. A simple method for the analysis of particle sizes of forage and total mixed rations. Journal of Dairy Science, Champaign, v. 79 , n. 5, p. $922-928$, 1996. DOI: $10.3168 /$ jds.S0022-0302(96)76442-1

MARI, L. J.; NUSSIO, L. G. O método Penn State Particle Size Separator para a predição do tamanho de partículas de silagens. AgriPoint Serviços de Informação Ltda., Piracicaba, 2002. Available at: https://www. beefpoint.com.br/o-metodo-penn-state-particle-sizeseparator-para-a-predicao-do-tamanho-de-particulas-desilagens-6531/. Accessed at: 30 june 2018.

McDONALD, P.; HENDERSON, A. R.; HERON, S. J. E. The biochemistry of silage. $2^{\text {th }}$ ed. Marlow Bucks: Chalcombe Publications, 1991. 340 p.

MERTENS, D. R. Gravimetric determination of amylasetreated neutral detergent fiber in feeds with refluxing beakers or crucibles: a collaborative study. Journal of $A O A C$, Washington, v. 85, n. 6, p. 1217-1240, 2002.

MUCK, R. E.; HOLMES, B. J. Factors affecting bunker silo densities. Applied Engineering in Agriculture, St. Joseph, v. 16, n. 6, p. 613-619, 2000.

NEUMANN, M.; LEÃO, G. F. M.; ASKEL, E. J.; MARAFON, F.; FIGUEIRA, D. N.; POCZYNEK, M. Sealing type effect on corn silage quality in bunker silos. Ciência Rural, Santa Maria, v. 47, n. 5, p. e20160643, 2017. DOI: $10.1590 / 0103-8478$ cr20160643

NEUMANN, M.; MÜHLBACH, P. R. F.; NÖRNBERG, J. L.; OST, P. R.; RESTLE, J.; SANDINI, I. E.; ROMANO, M. A. Características da fermentação da silagem obtida em diferentes tipos de silos sob efeito do tamanho de partícula e da altura de colheita das plantas de milho. Ciência Rural, Santa Maria, v. 37, n. 3, p. 847854, 2007.
NUSSIO, L. G. Cultura de milho para produção de silagem de alto valor alimentício. In: SIMPÓSIO SOBRE NUTRIÇÃO DE BOVINOS, 4., 1991, Piracicaba. Anais... Piracicaba: Fundação de Estudos Agrários Luiz de Queiroz, 1991. p. 59-168.

NUSSIO, L. G.; CAMPOS, F. P.; DIAS, F. N. Importância da qualidade da porção vegetativa no valor alimentício da silagem de milho. In: SIMPÓSIO SOBRE PRODUÇÃO E UTILIZAÇÃO DE FORRAGENS CONSERVADAS, 2001, Maringá. Anais... Maringá: UEM/CCA/DZO, 2001. p. 1-17.

OLIVEIRA, I. de; TABACCO, E.; FERRERO, F.; BORREANI, G.; BERNARDES, T. F. A new approach to assess feed-out rate in maize silage bunker. In: INTERNATIONAL SILAGE CONFERENCE, 18., 2018, Bonn. Proceedings... Bonn: OundZ Print, 2018. p. 454-455.

OLIVEIRA, J. S.; SOBRINHO, F. S.; REIS, F. A.; ROSA FILHO, S. N.; SOUZA, J. J. R.; MOREIRA, F. M.; PEREIRA, J. A.; FIRMINO, W. G. Adaptabilidade e estabilidade de cultivares de milho destinados à silagem em bacias leiteiras do estado de Goiás. Pesquisa Agropecuária Tropical, Goiânia, v. 37, n. 1, p. 45-50, 2007.

OLIVEIRA, L. B.; PIRES, A. J. V.; CARVALHO, G. G. P.; ALMEIDA, V. V.; PEIXOTO, C. A. M. Perdas e valor nutritivo de silagens de milho, sorgo-sudão, sorgo forrageiro e girassol. Revista Brasileira de Zootecnia, Viçosa, MG, v. 39, n. 1, p. 61-67, 2010.

OROSZ, S.; WILKINSON, J. M.; WIGLEY, S.; BIRO, Z.; GALLO, J. Oxygen barrier film improves fermentation, microbial status and aerobic stability of maize silage in the upper $30 \mathrm{~cm}$ of the silo. Agricultural and Food Science, Lemu, v. 22, n. 1, p. 182-188, 2013.

POSSENTI, R. A.; FERRARI JUNIOR, E.; BUENO, M. S.; BIANCHINI, D.; LEINZ, F. F.; RODRIGUES, C. F. Bromatological and fermentative parameters of corn and sunflower silages. Ciência Rural, Santa Maria, v. 35 , n. 5 , p. $1185-1189$, 2005. DOI: $10.1590 /$ S010384782005000500031

R DEVELOPMENT CORE TEAM - RDC Team. R: A language and environment for statistical computing. Vienna: R Foundation for Statistical Computing, 2018. Available at: http://www.R-project.org. Accessed at: 7 june 2018.

ROMAGNOLO, D.; POLAN, C. E.; BARBEAU, W. E. Electrophoretic analysis of ruminal degradability of corn proteins. Journal of Dairy Science, Champaign, v. 77 , n. 5 , p. $1093-1099$, 1994. DOI: $10.3168 /$ jds.S00220302(94)77044-2 
SANTOS, M. C.; GOLT, C.; JOERGER, R. D.; MECHOR, G. D.; MOURÃO, G. B.; KUNG JR, L. Identification of the major yeasts isolated from high moisture corn and corn silages in the United States using genetic and bio-chemical methods. Journal of Dairy Science, Champaign, v. 100, n. 2, p. 1151-1160, 2016. DOI: $10.3168 /$ jds.2016-11450

SATTER, L. D.; REIS, R. B. Milk production under confinement conditions. United States Department of Agriculture, Washington DC, 2012. Available at: http:// www.ars.usda.gov/research/ publications/ publications. htm? seq_no_115=84465. Accessed at: 01 june 2018 .

SAVOIE, P.; JOFRIET, J. C. Silage storge. In: BUXTON, D. R.; MUCK, R. E.; HARRISON, J. H. Silage science and technology. Madison: American Society of Agronomy, 2003. p. 405-468.

SENGER, C.; KOZLOSKI, G. V.; SANCHEZ, L. M. B.; MESQUITA, F. R.; ALVES, T. P.; CASTAGNINO, D. S. Evaluation of autoclave procedures for fibre analysis in forage and concentrate feedstuffs. Animal Feed Science and Technology, Amsterdam, v. 146, n. 1-2, p. 169-174, 2008. DOI: $10.1016 /$ j.anifeedsci.2007.12.008

SHINNERS, K. J. Engineering principles of silage harvesting equipement. In: BUXTON, D. R.; MUCK, R. E.; HARRISON, J. H. (Ed.). Silage science and technology. Madison: American Society of Agronomy, 2003. p. 361-404.

SILVA, D. J.; QUEIROZ, A. C. Análise de alimento: métodos químicos e biológicos. 3. ed. Viçosa, MG: Universidade Federal de Viçosa, 2002. 303 p.
SLAGHUIS, B. A.; TE GIFFEL, M. C.; BEUMER, R. R.; ANDRÉ, G. Effect of pasturing on the incidence of Bacillus spores in raw milk. International Dairy Journal, Amsterdam, v. 7, n. 4, p. 201-205, 1997. DOI: 10.1016/ S0958-6946(97)00012-5

TE GIFFEL, M. C.; WAGENDORP, A.; HERREWEGH, A.; DRIEHUIS, F. Bacterial spores in silage and raw milk. Antonie Van Leeuwenhoek, Nova Iorque, v. 81, n. 1-4, p. 625-630, 2002. DOI: 10.1023/A:1020578110353

WERNCKE, D.; GABBI, A. M.; ABREU, A. S.; FELIPUS, N. C.; MACHADO, N. L.; CARDOSO, L. L.; SCHMID, F. A.; ALESSIO, D. R. M.; FISCHER, V.; THALER, A. Qualidade do leite e perfil das propriedades leiteiras no sul de Santa Catarina: abordagem multivariada. Arquivo Brasileiro de Medicina Veterinária e Zootecnia, v. 68 , n. 2, p. 506-516, 2016.

WILKINSON, J. M.; BOLSEN, K. K.; LIN, C. J. History of silage. In: BUXTON, D. R.; MUCK, R. E.; HARRISON, J. H. Silage science and technology. Madison: American Society of Agronomy, 2003. p. 1-30.

WILKINSON, J. M.; FENLON, J. S. A meta-analysis comparing standard polyethylene and oxygen barrier film in terms of losses during storage and aerobic stability of silage. Grass and Forage Science, Nova Iorque, v. 69, n. 3, p. 385-392, 2013. DOI: $10.1111 /$ gfs. 12087

WINCKLER, J. P. P. Estratégias de vedação e adição de benzoato de sódio no controle de perdas em silagens de milho e desempenho de vacas leiteiras. 2015. Dissertação (Mestrado em Ciência Animal e Pastagens) - Escola Superior de Agricultura Luiz de Queiroz - Universidade de São Paulo, Piracicaba. 